\title{
BENTHIC MACROINVERTEBRATE COMMUNITIES IN THE NORTHERN TRIBUTARIES OF THE “IRON GATES” GORGE (DANUBE RIVER)
}

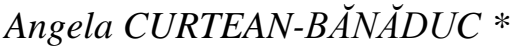

* "Lucian Blaga" University of Sibiu, Faculty of Sciences, Applied Ecology Research Center, Dr. Ioan Raţiu Street 5-7, Sibiu, Sibiu County, Romania, RO-550012, angela.banaduc@ulbsibiu.ro

DOI: 10.1515/trser-2015-0039

KEYWORDS: macroinvertebrates, Berzasca, Sirinia, Liubcova, Mraconia.

\section{ABSTRACT}

The paper presents the structure of the benthonic macro-invertebrates communities in the Berzasca, Sirinia, Liubcova, and Mraconia rivers. The results are based on quantitative benthos samples (95 samples), collected in July 2014 from 19 sampling stations within the study area. In longitudinal profile, the benthonic macro-invertebrate communities of the Sirinia, Liubcova and Berzasca rivers displays relatively large structural variability, while the communities of the Mraconia River displays smaller structural variability. The structure of the benthonic macro-invertebrate communities correlated with the biotope characteristics indicates the good ecological status of the analysed rivers, with the exception of the Berzasca River sector downstream of the town of Berzasca and immediately upstream of the Danube junction, a sector with moderate ecological status due to negative effects from man-made modifications in the lotic biotope of the sector.

RE்SUME்: Les communautés de macroinvertébrés benthiques des affluents nord du Danube, dans la région des Portes de Fer.

L'article décrit la structure des communautés de macroinvertébrés benthiques des rivières de Berzasca, Sirinia, Liubcova et Mraconia. Les résultats obtenus sont basés sur des échantillons quantitatifs de benthos (95 échantillons) collectés en juillet 2014 sur 19 stations d'échantillonnage situées dans la zone de référence. En profil longitudinal, les communautés de macroinvertébrés benthiques des rivières de Sirinia, Liubcova et Berzasca présentent une variabilité structurelle assez importante, alors que les communautés de la rivière de Mraconia présentent une moindre variabilité structurelle. La structure des communautés de macroinvertébrés benthiques corrélée aux caractéristiques du biotope relèvent du bon état écologique des rivières analysées, à l'exception de la rivière de Berzasca en aval de la ville de Berzasca, juste avant la confluence avec le Danube, secteur présentant un état écologique modéré, dû à la modification anthropique du biotope lotique dans ce secteur.

REZUMAT: Comunitățile de macronevertebrate bentonice din afluenții nordici ai Dunării, în zona Porțile de Fier.

Lucrarea prezintă descrierea structurii comunităţilor de macronevertebrate bentonice din râurile Berzasca, Sirinia, Liubcova și Mraconia. Rezultatele se bazează pe probe cantitative de bentos (95 probe), colectate în iulie 2014 din 19 staţii de colectare situate în zona de referință. În profil longitudinal, comunitățile de macronevertebrate bentonice din râurile Sirinia, Liubcova și Berzasca prezintă variabilitate structurală relativ mare, iar cele din râul Mraconia prezintă variabilitate structurală mai mică. Structura comunităților de macronevertebrate bentonice în corelație cu caracteristicile biotopului relevă faptul că râurile analizate prezintă o stare ecologică bună, cu excepția sectorului râului Berzasca situat aval de localitatea Berzasca, imediat amonte de confluența cu Dunărea, care prezintă stare ecologică moderată, în acest sector biotopul lotic este modificat antropic. 


\section{INTRODUCTION}

Construction of the "Iron Gates" I (1972) for hidroenergy and navigation complex modified the hydrological regime of the Danube and its tributaries at the confluence with the newly-created reservoir lake (Ujvari, 1959). After the dam was constructed across the Gura Valley, and the reservoir lake was formed, the river mouths of all Danube tributaries became flooded and turned into bays.

Considering these aspects, this study aims to analyze the longitudinal dynamics of the benthic macroinvertebrate communities of the Danube tributaries flowing from the left side, from the "Iron Gates" area (Fig. 1): Berzasca River, with a catchment area of $229 \mathrm{~km}^{2}$; Sirinia, with a catchment area of $74.2 \mathrm{~km}^{2}$, and Mraconia, with a catchment area of $113 \mathrm{~km}^{2}$ (Tetelea, 2014).

These rivers have their sources in the Almăj Mountains and cross some sparse settlements at the confluence with the Danube. The study area is part of the "Iron Gates" Natural Park.

These analyzed rivers are classified as western Carpathian type, characterised by flood waters during spring and winter, while winter leakage is more important, due to Mediterranean climate influences which induces the early melting of snow. Rivers are short with large slopes and relatively high flow rates, resulting in a large volume of alluvial material dislocated from the riverbed (Ujvari, 1959).

Studies of the invertebrate communities in northern Danube tributaries of the "Iron Gates” were conducted during 1959 to 1970, before the dam construction and reservoir filling: Botoşănenu (1959) studied fauna of caddisflies, Prunescu-Arion (1968) recorded data on benthic fauna, Antonescu et al. (1969) carried out hydrobiological research on rivers Berzasca and Sirinia, Brezeanu, Prunescu-Arion, and Popescu Marinescu (in Buşniță et al., 1970) studied the taxonomic structure of macroinvertebrate communities in the rivers: Bozneaţca, Varada, Sicolovăț, Alibeg, Liuborajdea, Cruşovăţ, Cameniţa, Oraviţa, Berzasca, Sirinia, Elişeva, Povalina, Tisova, Plavişevița, Mraconia, Eşelniţa, Cerna, Vodiţa, Bahna, and Dubova. (Badea et al. 1983; Posea, 1982; Roşu, 1980).

\section{MATERIAL AND METHODS}

The results are based on quantitative benthic macroinvertebrate samples (95 samples) taken in July 2014 from 19 stations of the reference areas, located at approximately five $\mathrm{km}$ intervals along the four studied Danube tributaries (Fig. 2).

In each station, quantitative samples were taken from five separate points, in order to highlight the specific diversity of local micro-habitats. The sampling was carried out with an $887 \mathrm{~cm}^{2}$ surface Surber Sampler, with a $250 \mu \mathrm{m}$ mesh net. The sampled biological material was fixed in $4 \%$ formaldehyde solution and was analyzed in the laboratory with an Olympus (150X) stereomicroscope. The invertebrates were identified to order except Oligochaeta, Hirudinea and Chironomidae and the counts were converted to number of individuals per square meter (ind. $/ \mathrm{m}^{2}$ ). For the quantitative structure description of the macroinvertebrate communities we used relative abundance (A\%) and mean density (Ds) measures.

The assessed biotope variables were: altitude, slope, riverbed width, depth, substratum types, channel modification (expressed as a percentage in comparison to the natural state), riverine vegetation and water physico-chemical characteristics $(\mathrm{pH}$, total dissolved solids TDS, dissolved oxygen - DO). The substratum types (mud, sand, gravel, pebbles, cobbles, and boulders) were expressed as percentages of the transversal section surface (20 m length). 


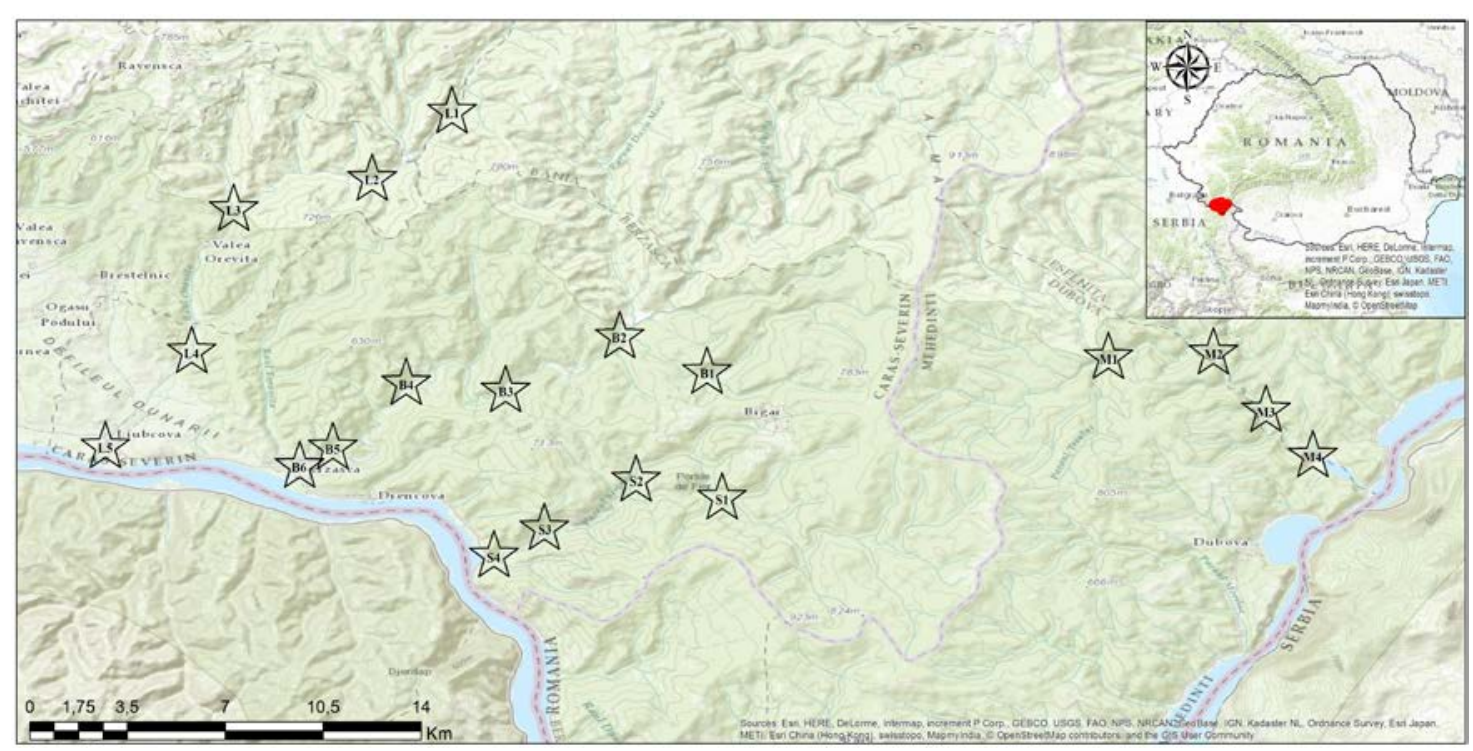

Figure 1: The sampling stations location on the studied rivers: Berzasca (B1 - B6), Sirinia (S1 - S4), Liubcova (L1 - L5), Mraconia (M1 - M4).

\section{RESULTS AND DISCUSSION}

The benthic macroinvertebrate groups with the largest distribution in the reference area are Ephemeroptera, Plecoptera, Trichoptera, and Chironomida, present in all the analysed river sectors. Groups with a more restricted distribution included the Tricladida, Gastropoda, Oligochaeta, Hydracarina, Amphipoda, Odonata, Heteroptera, Coleoptera, and Dipterans other than Chironomidae Family (Tab. 1).

The similarity analysis of the benthic macroinvertebrate communities in the six lotic sectors studied on the Berzasca River, based on the relative abundance values of the present taxa, reveals the fact that they can be classified into five groups (Fig. 3; Tab. 1): I. communities dominated numerically by Ephemeropterans, accompanied by the Planaria, the Trichopterans and the Chironomids, with relative abundances between $10 \%$ and $13 \%$, present in B1; II. communities dominated numerically by Ephemeropterans and Trichopterans, accompanied by the Oligochetes and the Plecopterans with relative abundances between $15 \%$ and 20\%, present in B3; III. communities dominated numerically by Ephemeropterans and Plecopterans, in which Oligochetae present relative abundances comprised between $15 \%$ and $20 \%$, present in B2 and B4; IV. communities dominated numerically by Ephemeropterans and Plecopterans, accompanied by Trichopterans and Chironomids with relative abundances between $13 \%$ and $19 \%$, present in B5; V. communities dominated numerically by Chironomids, present in B6. A relatively large structural difference was found between communities from the sectors B1 - B5 and that of sector B6 - upstream of the Danube confluence, an area where the lotic habitat is modified by humans and impacted by pollution from waste water and domestic waste generated by the village of Berzasca. 


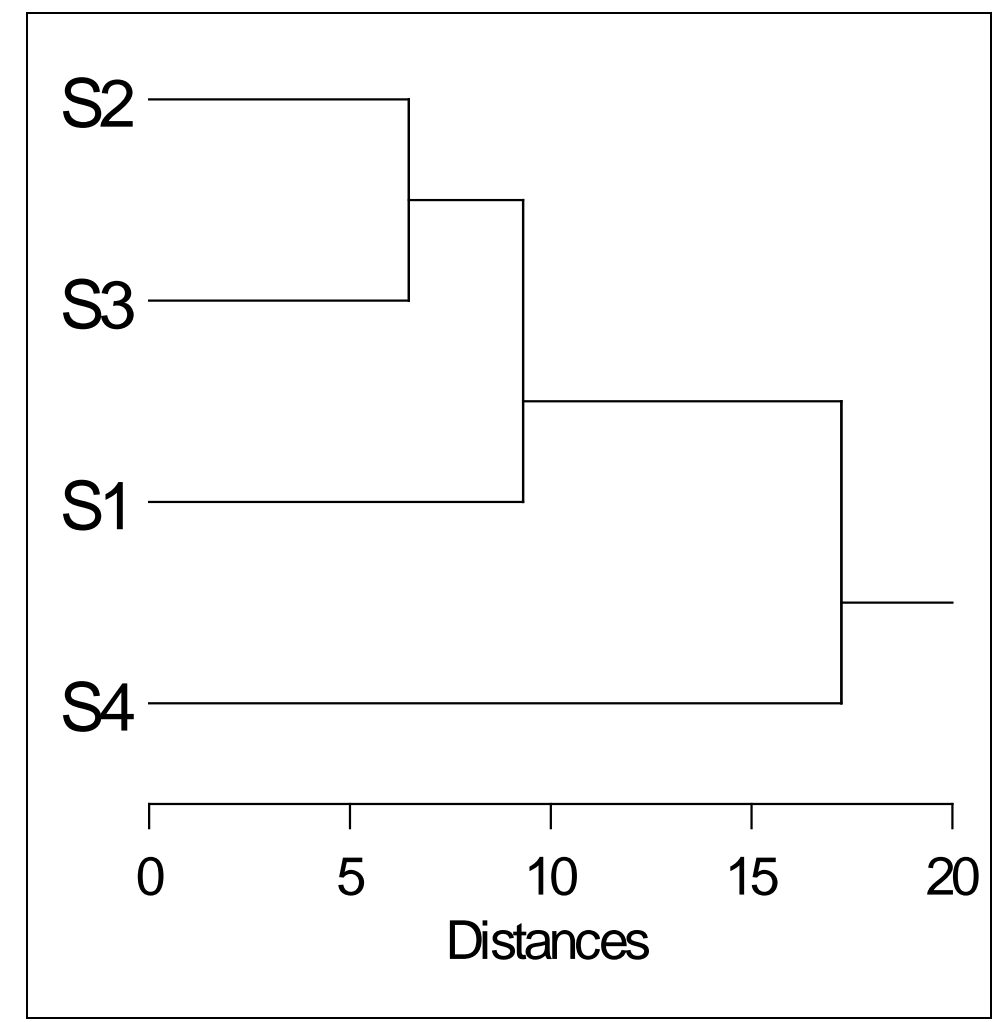

Figure 2: Cluster analysis based on the benthic macroinvertebrate systematic groups relative abundence (A\%), of the four analysed lotic sectors of the Sirinia River (euclidian distances, S1 - S4 sampling stations).

The benthic macroinvertebrate communities of Sirinia River present a relatively high structural variability along the river (Fig. 2, Tab. 1).

In the upper river sector - sector S1 - the numerically dominant taxa are the Ephemeroptera and the Trichoptera, followed by Chyronomida. In this sector, Plectoperans have a relative abundance smaller than 10\%, Amphipods and Dipterans have relative abundances between $12 \%$ and 20\%; sector S2 is numerically dominated by Ephemeropterans, Oligochetae and Dipterans, and, with relative abundances less than $10 \%$, Plecopterans, Trichopterans, Turbelariatae and Coleopterans; downstream, sector S3 is numerically dominated by Ephemeropterans and Dipterans, with lower abundances of Trichopterans (18.64\%) and Plecopterans (13.28\%), and, with relative abundances under 7\%, by Oligochetae, Coleopterans, Amfipods, Turbelariates and Hydracarians; in the lower sector - sector S4 - the Chironomids dominate in numbers, followed by Oligochaeta with relative abundances of 17.23\%, with Ephemeropterans, Plecopterans, Trichopterans, Turbelariates, Amfipodes and Hydracarians also being present. 


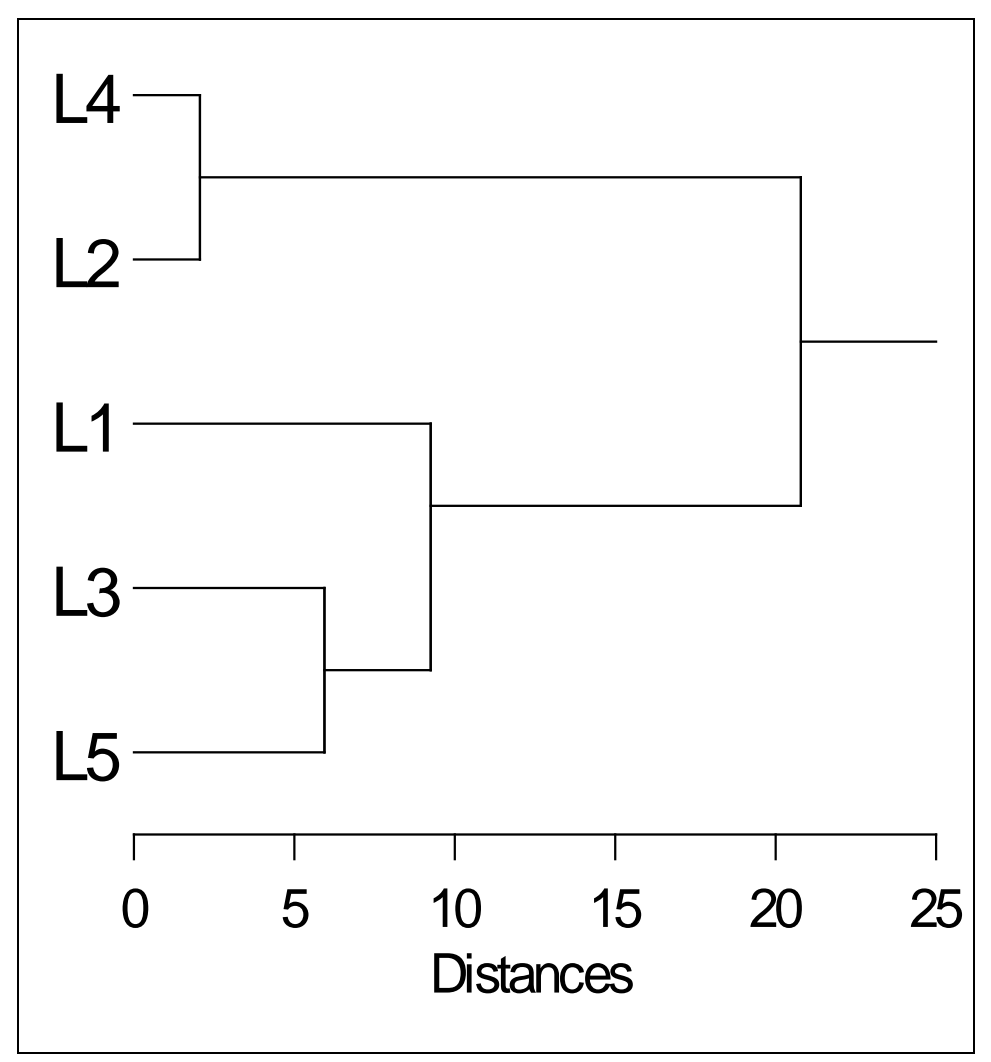

Figure 3: Cluster analysis based on the benthic macroinvertebrate systematic groups relative abundence (A\%), of the five analysed lotic sectors of the Liubcova River

(euclidian distances, L1 - L5 sampling stations).

Based on the values of relative abundances of the present taxa, the benthic macroinvertebrate communities of the five river sectors analysed along the Liubcova River can be classified in three groups (Fig. 3, Tab. 1): I. Communities dominated numerically by Amphipodes, with Plecopterans and Ephemeropterans present at abundances between $7 \%$ and $15 \%$, and Trichopterans, Oligochetae and the Dipterans present in relative abundances under 5\%, all present in L2 and L4; II. Communities dominated numerically by Ephemeropterans, with Amphipodes and Plecopterans at lower abundances, and Dipterans, Trichopterans and Oligochetae in relative abundances under 4\%, present in L1; III. Communities dominated by Ephemeropterans and Oligochetae, accompanied in variable proportions by Dipterans, Plecopterans, Coleopterans and Amfipodes, present in L3 and L5. 


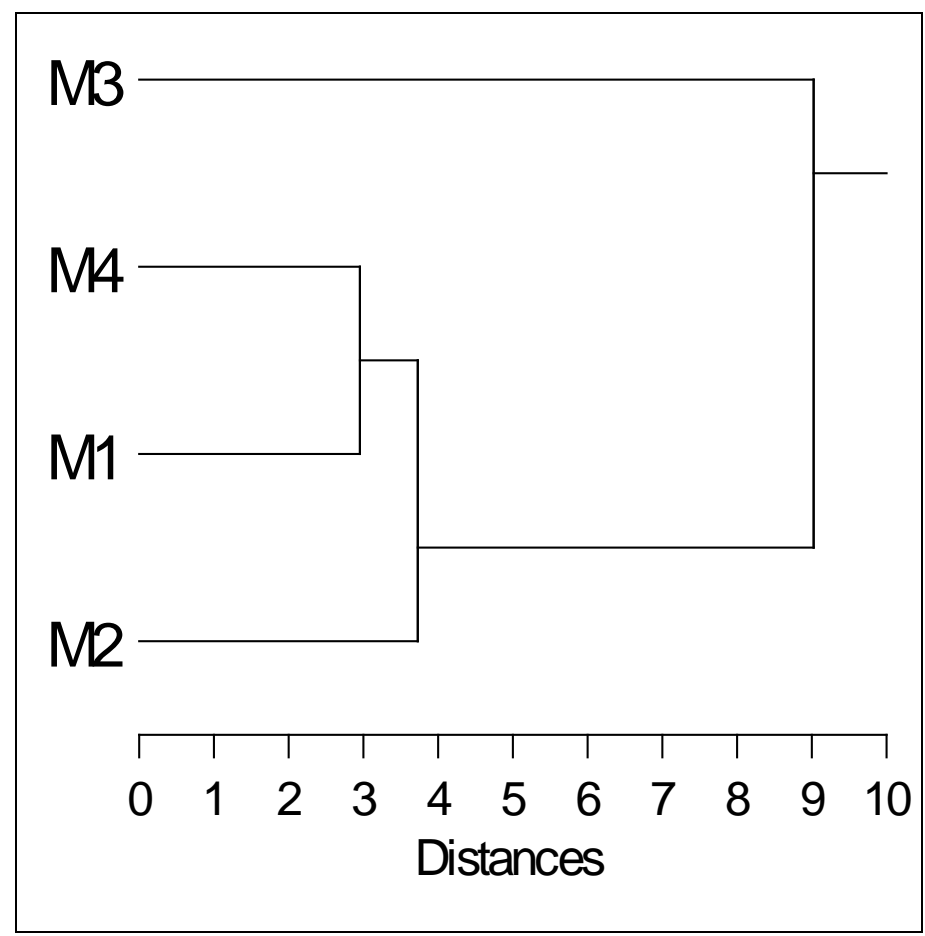

Figure 4: Cluster analysis based on the benthic macroinvertebrate systematic groups relative abundence (A\%), of the four analysed lotic sectors of the Mraconia River (euclidian distances, M1 - M4 sampling stations).

Benthic macroinvertebrate communities of all four studied sectors along Mraconia River have a relatively small structural variability (Fig. 4, Tab. 1), and they can be grouped in two classes: I. Communities in which Ephemeropterans and Plecopterans are numerically codominant, with Oligochaetes and Dipterans present in relative abundances ranged between $10 \%$ and $19 \%$, and Trichopterans, Coleopterans and Amphipods present in abundances smaller than 10\%, present in M1, M2 and M4; II. Communities in which Dipterans and Ephemeropterans are numerically co-dominant, with Oligochaetes and Plectopterans present in small abundances $(10.59 \%$ and $8.84 \%$ respectively), and Trichopterans, Amphipods, Coleopterans and water mites present with relative abundances smaller than $5 \%$, present in M3. 


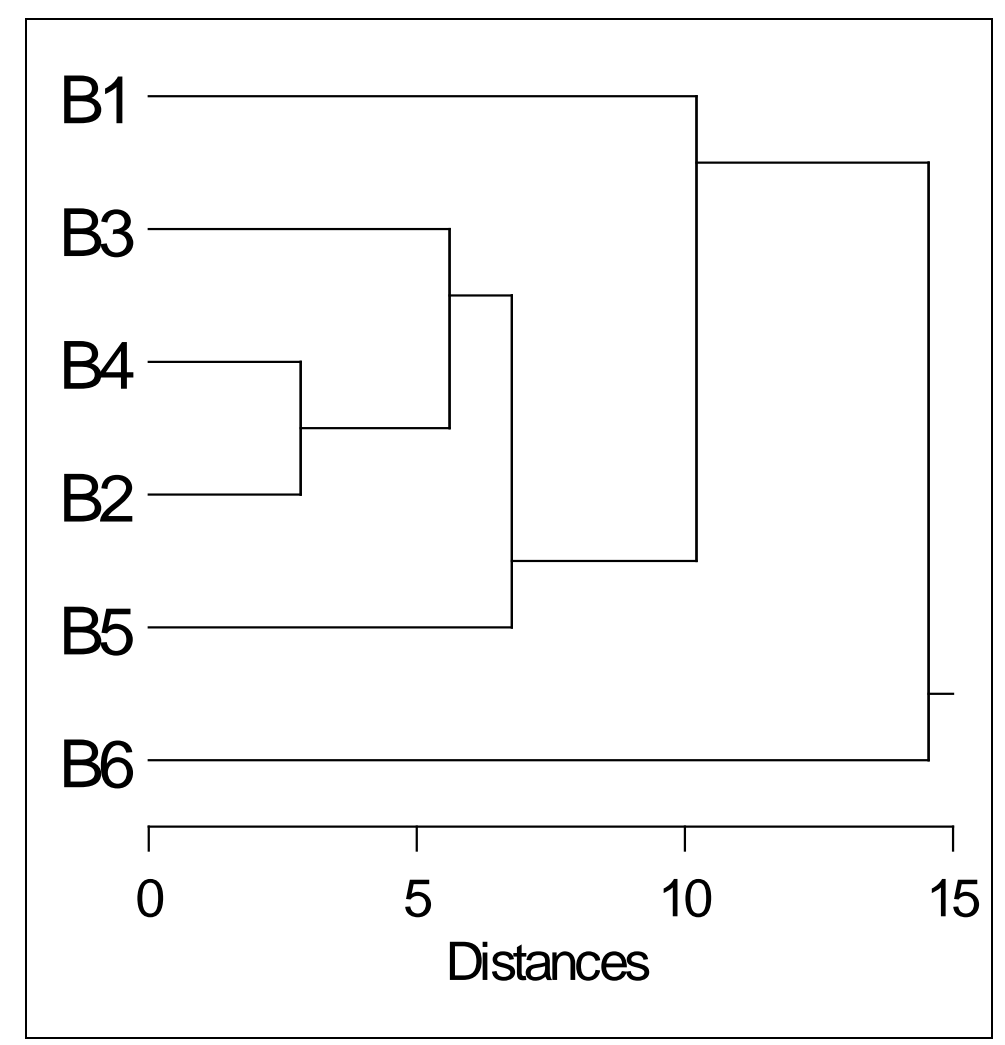

Figure 5: Cluster analysis based on the benthic macroinvertebrate systematic groups relative abundence (A\%), of the six analysed lotic sectors from the Berzasca River (euclidian distances, B1 - B6 sampling stations).

In the reference area, the highest density of benthic macroinvertebrates was recorded in Berzasca River (Fig. 5, Tab. 1), within the sector placed at $5.5 \mathrm{~km}$ upstream of the confluence with the Danube (B5).

High density of Plecopterans is associated with river sectors with a fast flow and a substratum predominantly formed of cobbles and boulders; Ephemeropterans develop populations with a large number of individuals in most of the river sectors, except the sectors in which sedimentary substratum is prevalent - sand and mud. In the case of the other benthic sectors, a dependence pattern of the density on the prevalent substratum type cannot be described in a certain sector.

In terms of biotope conditions, although they occur at relatively low altitudes (under $375 \mathrm{~m}$ ), the studied rivers have a mountain character up to about 5-6 km upstream the confluence with the Danube, with well oxygenated waters, slightly basic $\mathrm{pH}$ and a content of total dissolved solids ranging between $207 \mathrm{mg} / \mathrm{l}$ (in M1) and 364 mg/l (in L4 and L5) (Tab. 1). 
Table 1: Benthic macroinvertebrate community structure in Berzasca River (B1 - B6), Sirinia River (S1 - S4), Liubcova River (L1 - L5) and Mraconia River (M1 - M4), (Ds - mean density, A\% - relative abundance) and riverbed characteristics (Wm - minimum width, WA average width, WM - maximum width, Dm - minimum depth, DA - average depth, DM maximum depth, $\mathrm{m}$ - mud, $\mathrm{s}$ - sand, $\mathrm{g}$ - gravel, $\mathrm{p}$ - pebbles, c - cobbles, b - boulders, $\mathrm{g}+\mathrm{m}$ gravel covered with thin layer of mud).

\begin{tabular}{|c|c|c|c|}
\hline \multirow[b]{2}{*}{$\begin{array}{l}\text { Sampling station/position, altitude, } \\
\text { biotope characteristics }\end{array}$} & \multicolumn{3}{|c|}{ Benthic macroinvertebrate community structure } \\
\hline & $\begin{array}{l}\text { Taxonomic } \\
\text { groups }\end{array}$ & $\begin{array}{c}\text { Ds } \\
\text { (ind. } / \mathrm{m}^{2} \text { ) }\end{array}$ & $\begin{array}{c}\text { A } \\
(\%)\end{array}$ \\
\hline \multirow{10}{*}{ 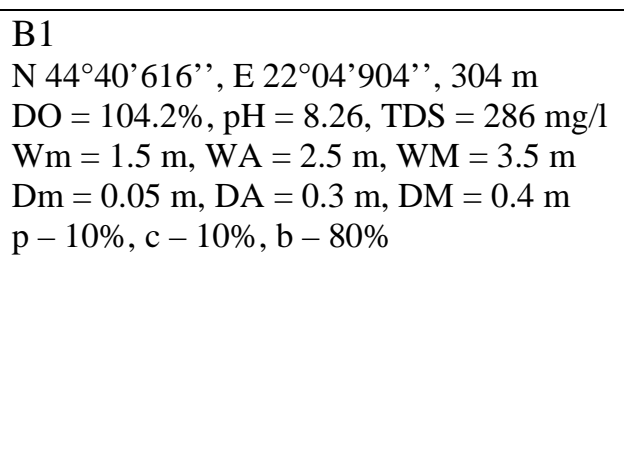 } & Tricladida & 126.27 & 10.04 \\
\hline & Gastropoda (A. fluviatilis) & 13.53 & 1.08 \\
\hline & Oligochaeta & 13.53 & 1.08 \\
\hline & Amphypoda & 6.76 & 0.54 \\
\hline & Ephemeroptera & 651.63 & 51.79 \\
\hline & Plecoptera & 63.13 & 5.02 \\
\hline & Trichoptera & 153.33 & 12.19 \\
\hline & Coleoptera & 11.27 & 0.90 \\
\hline & Chironomidae & 162.34 & 12.90 \\
\hline & other Diptera & 56.37 & 4.48 \\
\hline \multirow{10}{*}{$\begin{array}{l}\text { B2 } \\
\text { N 4441'302', E } 22^{\circ} 03^{\prime} 205^{\prime \prime}, 228 \mathrm{~m} \\
\text { DO = 104.1\%, pH = 8.15, TDS = } 240 \mathrm{mg} / \mathrm{l} \\
\text { Wm }=5 \mathrm{~m}, \mathrm{WA}=7 \mathrm{~m}, \mathrm{WM}=9 \mathrm{~m} \\
\text { Dm }=0.1 \mathrm{~m}, \mathrm{DA}=0.3 \mathrm{~m}, \mathrm{DM}=1.2 \mathrm{~m} \\
\mathrm{~s}-3 \%, \mathrm{p}-7 \%, \mathrm{c}-40 \%, \mathrm{~b}-50 \%\end{array}$} & Tricladida & 22.55 & 1.83 \\
\hline & Oligochaeta & 200.68 & 16.30 \\
\hline & Hydracarina & 11.27 & 0.92 \\
\hline & Amphypoda & 29.31 & 2.38 \\
\hline & Ephemeroptera & 405.86 & 32.97 \\
\hline & Plecoptera & 266.07 & 21.61 \\
\hline & Trichoptera & 105.98 & 8.61 \\
\hline & Coleoptera & 54.11 & 4.40 \\
\hline & Chironomidae & 101.47 & 8.24 \\
\hline & other Diptera & 33.82 & 2.75 \\
\hline \multirow{9}{*}{ 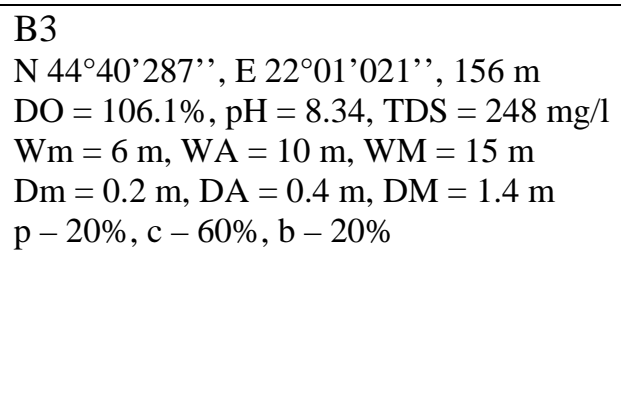 } & Oligochaeta & 205.19 & 18.24 \\
\hline & Hydracarina & 2.25 & 0.20 \\
\hline & Amphypoda & 6.76 & 0.60 \\
\hline & Ephemeroptera & 311.16 & 27.66 \\
\hline & Plecoptera & 209.7 & 18.64 \\
\hline & Trichoptera & 304.4 & 27.05 \\
\hline & Coleoptera & 2.25 & 0.20 \\
\hline & Chironomidae & 60.88 & 5.41 \\
\hline & other Diptera & 22.55 & 2.00 \\
\hline
\end{tabular}


Table 1 (continued): Benthic macroinvertebrate community structure in Berzasca River (B1 - B6), Sirinia River (S1 - S4), Liubcova River (L1 - L5) and Mraconia River (M1 M4), (Ds - mean density, A\% - relative abundance) and riverbed characteristics (Wm minimum width, WA - average width, WM - maximum width, Dm - minimum depth, DA average depth, DM - maximum depth, $\mathrm{m}$ - mud, $\mathrm{s}$ - sand, g - gravel, $\mathrm{p}$ - pebbles, c - cobbles, $\mathrm{b}$ - boulders, $\mathrm{g}+\mathrm{m}$ - gravel covered with thin layer of mud).

\begin{tabular}{|c|c|c|c|}
\hline \multirow[b]{2}{*}{$\begin{array}{l}\text { Sampling station/position, altitude, } \\
\text { biotope characteristics }\end{array}$} & \multicolumn{3}{|c|}{ Benthic macroinvertebrate community structure } \\
\hline & $\begin{array}{l}\text { Taxonomic } \\
\text { groups }\end{array}$ & $\begin{array}{c}\text { Ds } \\
\text { (ind./m²) }\end{array}$ & $\begin{array}{c}\mathrm{A} \\
(\%)\end{array}$ \\
\hline \multirow{12}{*}{ 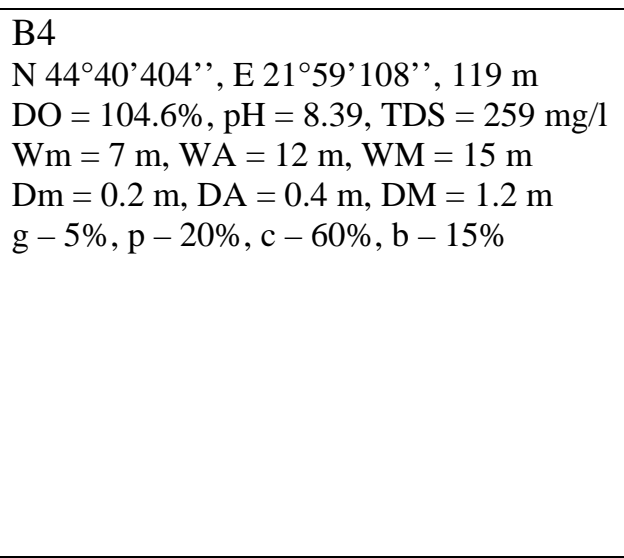 } & Tricladida & 2.25 & 0.17 \\
\hline & Gastropoda (A. fluviatilis) & 94.7 & 7.08 \\
\hline & Oligochaeta & 263.81 & 19.73 \\
\hline & Hydracarina & 18.04 & 1.35 \\
\hline & Amphypoda & 18.04 & 1.35 \\
\hline & Ephemeroptera & 372.04 & 27.82 \\
\hline & Odonata & 4.51 & 0.34 \\
\hline & Plecoptera & 302.14 & 22.60 \\
\hline & Trichoptera & 119.5 & 8.94 \\
\hline & Coleoptera & 18.04 & 1.35 \\
\hline & Chironomidae & 101.47 & 7.59 \\
\hline & other Diptera & 22.55 & 1.69 \\
\hline \multirow{11}{*}{ 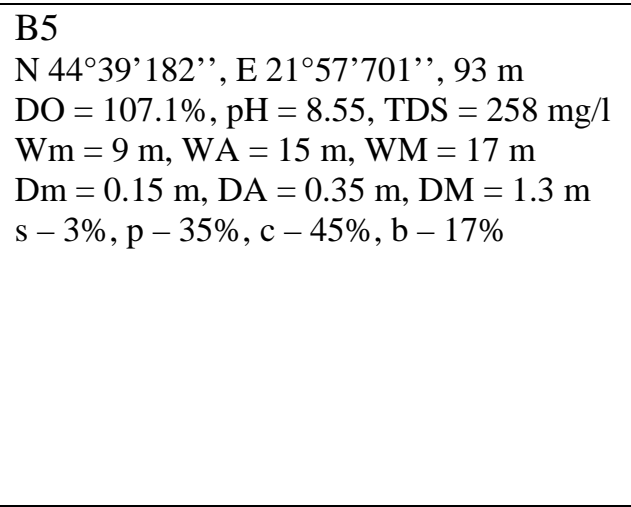 } & Gastropoda (A. fluviatilis) & 27.06 & 1.02 \\
\hline & Oligochaeta & 105.98 & 4.01 \\
\hline & Hydracarina & 36.08 & 1.37 \\
\hline & Amphypoda & 4.51 & 0.17 \\
\hline & Ephemeroptera & 671.93 & 25.43 \\
\hline & Plecoptera & 868.09 & 32.85 \\
\hline & Heteroptera & 6.77 & 0.26 \\
\hline & Trichoptera & 358.51 & 13.57 \\
\hline & Coleoptera & 36.08 & 1.37 \\
\hline & Chironomidae & 496.05 & 18.77 \\
\hline & other Diptera & 38.33 & 1.45 \\
\hline \multirow{10}{*}{ 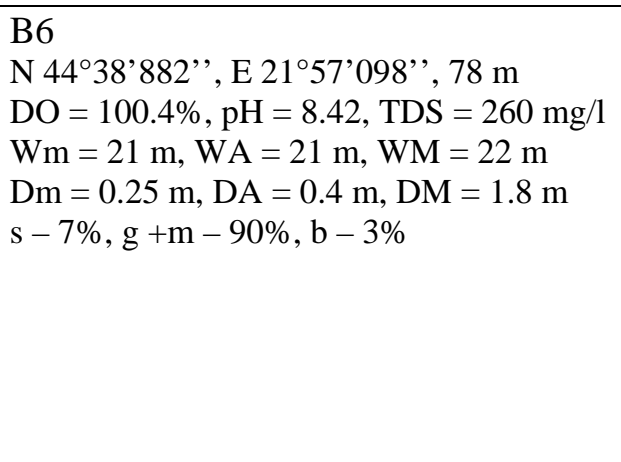 } & Gastropoda (A. fluviatilis) & 11.27 & 1.37 \\
\hline & Oligochaeta & 74.41 & 9.04 \\
\hline & Hydracarina & 18.04 & 2.19 \\
\hline & Ephemeroptera & 196.17 & 23.84 \\
\hline & Odonata & 2.25 & 0.27 \\
\hline & Plecoptera & 42.84 & 5.21 \\
\hline & Trichoptera & 15.78 & 1.92 \\
\hline & Coleoptera & 6.76 & 0.82 \\
\hline & Chironomidae & 450.96 & 54.80 \\
\hline & other Diptera & 4.51 & 0.55 \\
\hline
\end{tabular}


Table 1 (continued): Benthic macroinvertebrate community structure in Berzasca River (B1 - B6), Sirinia River (S1 - S4), Liubcova River (L1 - L5) and Mraconia River (M1 M4), (Ds - mean density, A\% - relative abundance) and riverbed characteristics (Wm minimum width, WA - average width, WM - maximum width, Dm - minimum depth, DA average depth, DM - maximum depth, $\mathrm{m}$ - mud, $\mathrm{s}$ - sand, $\mathrm{g}$ - gravel, $\mathrm{p}$ - pebbles, c - cobbles, $\mathrm{b}$ - boulders, $\mathrm{g}+\mathrm{m}$ - gravel covered with thin layer of mud).

\begin{tabular}{|c|c|c|c|}
\hline \multirow{6}{*}{ 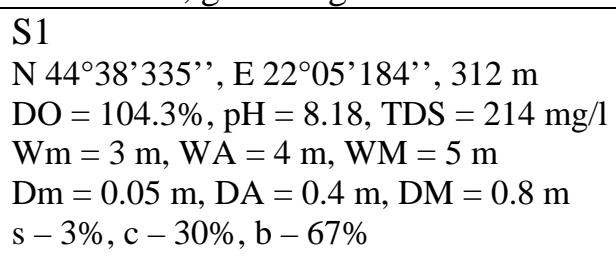 } & Amphypoda & 36.08 & 4.09 \\
\hline & Ephemeroptera & 266.07 & 30.18 \\
\hline & Plecoptera & 78.92 & 8.95 \\
\hline & Trichoptera & 286.36 & 32.48 \\
\hline & Chironomidae & 198.42 & 22.51 \\
\hline & other Diptera & 15.78 & 1.79 \\
\hline \multirow{9}{*}{ 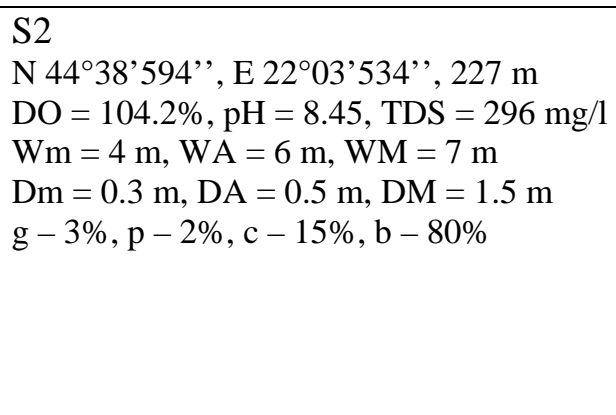 } & Tricladida & 13.53 & 3.41 \\
\hline & Oligochaeta & 49.61 & 12.50 \\
\hline & Hydracarina & 2.25 & 0.57 \\
\hline & Ephemeroptera & 180.38 & 45.45 \\
\hline & Plecoptera & 31.57 & 7.96 \\
\hline & Trichoptera & 31.57 & 7.96 \\
\hline & Coleoptera & 9.02 & 2.27 \\
\hline & Chironomidae & 33.82 & 8.52 \\
\hline & other Diptera & 45.1 & 11.36 \\
\hline \multirow{10}{*}{ 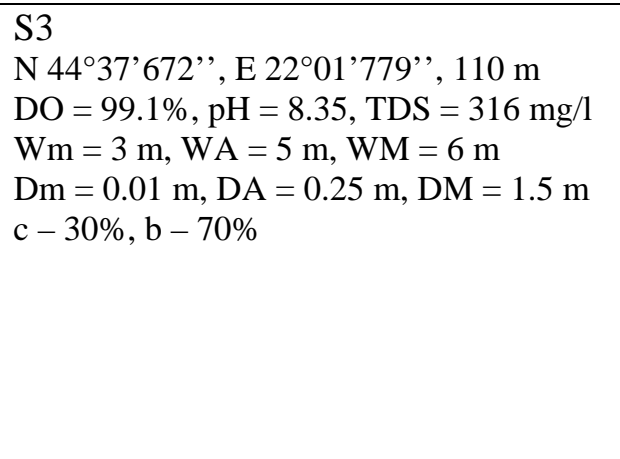 } & Tricladida & 4.51 & 0.57 \\
\hline & Oligochaeta & 51.86 & 6.50 \\
\hline & Hydracarina & 2.25 & 0.28 \\
\hline & Amphypoda & 4.51 & 0.57 \\
\hline & Ephemeroptera & 239.01 & 29.94 \\
\hline & Plecoptera & 105.98 & 13.28 \\
\hline & Trichoptera & 148.82 & 18.64 \\
\hline & Coleoptera & 22.55 & 2.83 \\
\hline & Chironomidae & 45.1 & 5.65 \\
\hline & other Diptera & 173.62 & 21.75 \\
\hline \multirow{8}{*}{ 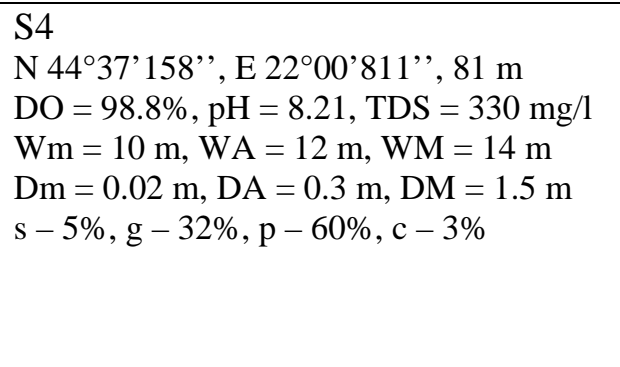 } & Oligochaeta & 173.62 & 17.23 \\
\hline & Amphypoda & 13.53 & 1.34 \\
\hline & Ephemeroptera & 99.21 & 9.84 \\
\hline & Plecoptera & 74.41 & 7.38 \\
\hline & Trichoptera & 22.55 & 2.24 \\
\hline & Coleoptera & 9.02 & 0.89 \\
\hline & Chironomidae & 613.3 & 60.85 \\
\hline & other Diptera & 2.25 & 0.22 \\
\hline
\end{tabular}


Table 1 (continued): Benthic macroinvertebrate community structure in Berzasca River (B1 - B6), Sirinia River (S1 - S4), Liubcova River (L1 - L5) and Mraconia River (M1 M4), (Ds - mean density, A\% - relative abundance) and riverbed characteristics (Wm minimum width, WA - average width, WM - maximum width, Dm - minimum depth, DA average depth, DM - maximum depth, $\mathrm{m}$ - mud, $\mathrm{s}$ - sand, g - gravel, $\mathrm{p}$ - pebbles, c - cobbles, $\mathrm{b}$ - boulders, $\mathrm{g}+\mathrm{m}$ - gravel covered with thin layer of mud).

\begin{tabular}{|c|c|c|c|}
\hline \multirow{8}{*}{ 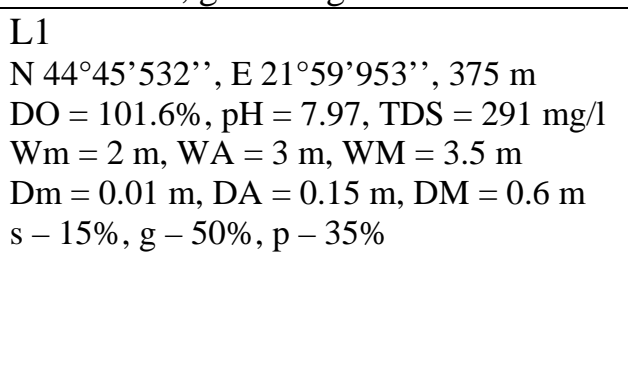 } & Tricladida & 2.25 & 0.30 \\
\hline & Oligochaeta & 9.02 & 1.20 \\
\hline & Amphypoda & 162.34 & 21.62 \\
\hline & Ephemeroptera & 401.35 & 53.45 \\
\hline & Plecoptera & 135.29 & 18.02 \\
\hline & Trichoptera & 9.02 & 1.20 \\
\hline & Chironomidae & 29.31 & 3.90 \\
\hline & other Diptera & 2.25 & 0.30 \\
\hline \multirow{6}{*}{ 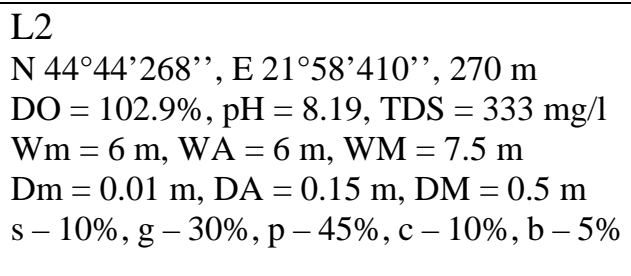 } & Oligochaeta & 13.53 & 1.54 \\
\hline & Amphypoda & 622.32 & 70.95 \\
\hline & Ephemeroptera & 124.01 & 14.14 \\
\hline & Plecoptera & 103.72 & 11.83 \\
\hline & Trichoptera & 11.27 & 1.28 \\
\hline & Chironomidae & 2.25 & 0.26 \\
\hline \multirow{8}{*}{ 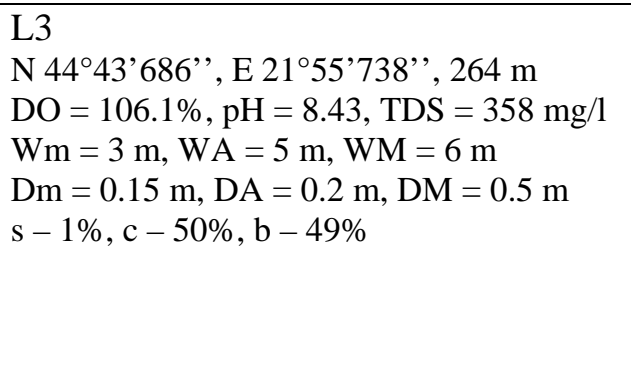 } & Oligochaeta & 133.04 & 18.55 \\
\hline & Amphypoda & 40.59 & 5.66 \\
\hline & Ephemeroptera & 299.89 & 41.81 \\
\hline & Plecoptera & 65.38 & 9.12 \\
\hline & Trichoptera & 115 & 16.03 \\
\hline & Coleoptera & 15.79 & 2.20 \\
\hline & Chironomidae & 18.18 & 2.53 \\
\hline & other Diptera & 29.32 & 4.09 \\
\hline \multirow{7}{*}{$\begin{array}{l}\text { L4 } \\
\text { N } 44^{\circ} 40^{\prime} 999,, \text { E } 21^{\circ} 54^{\prime} 919^{\prime \prime}, 124 \mathrm{~m} \\
\text { DO = 102.5\%, pH = 8.31, TDS = } 364 \mathrm{mg} / \mathrm{l} \\
\text { Wm }=4.5 \mathrm{~m}, \mathrm{WA}=6 \mathrm{~m}, \mathrm{WM}=7 \mathrm{~m} \\
\mathrm{Dm}=0.1 \mathrm{~m}, \mathrm{DA}=0.15 \mathrm{~m}, \mathrm{DM}=1 \mathrm{~m} \\
\mathrm{~s}-5 \%, \mathrm{~g}-85 \%, \mathrm{p}-10 \%\end{array}$} & Oligochaeta & 29.31 & 1.50 \\
\hline & Amphypoda & 1379.93 & 70.51 \\
\hline & Ephemeroptera & 153.33 & 7.83 \\
\hline & Plecoptera & 257.05 & 13.13 \\
\hline & Trichoptera & 87.94 & 4.49 \\
\hline & Chironomidae & 36.08 & 1.84 \\
\hline & other Diptera & 13.53 & 0.69 \\
\hline \multirow{7}{*}{ 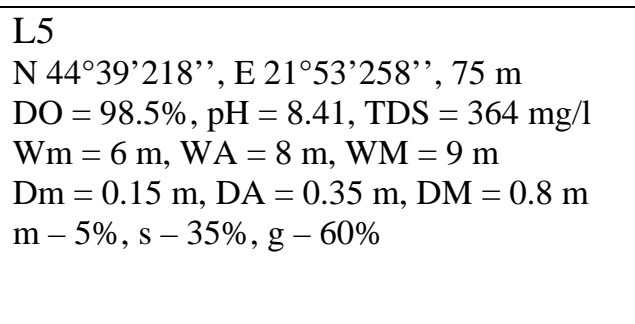 } & Oligochaeta & 347.24 & 18.58 \\
\hline & Amphypoda & 2.25 & 0.12 \\
\hline & Ephemeroptera & 899.66 & 48.13 \\
\hline & Plecoptera & 112.74 & 6.03 \\
\hline & Trichoptera & 139.8 & 7.48 \\
\hline & Chironomidae & 363.02 & 19.42 \\
\hline & other Diptera & 4.51 & 0.24 \\
\hline
\end{tabular}


Table 1 (continued): Benthic macroinvertebrate communitystructure in Berzasca River (B1 - B6), Sirinia River (S1 - S4), Liubcova River (L1 - L5) and Mraconia River (M1 - M4), (Ds - mean density, A\% - relative abundance) and riverbed caracteristics (Wm - minimum width, WA - average width, WM - maximum width, Dm - minimum depth, DA - average depth, DM - maximum depth, $\mathrm{m}$ - mud, s - sand, g - gravel, $\mathrm{p}$ - pebbles, c - cobbles, b boulders, $\mathrm{g}+\mathrm{m}$ - gravel covered with thin layer of mud).

\begin{tabular}{|c|c|c|c|}
\hline \multirow{8}{*}{ 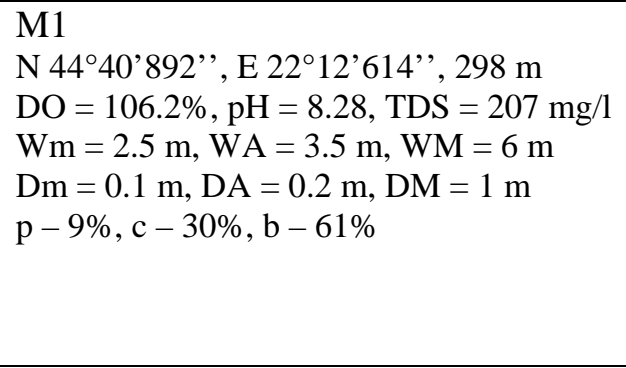 } & Oligochaeta & 250.28 & 12.82 \\
\hline & Amphypoda & 38.33 & 1.96 \\
\hline & Ephemeroptera & 744.08 & 38.11 \\
\hline & Plecoptera & 387.82 & 19.86 \\
\hline & Trichoptera & 126.27 & 6.47 \\
\hline & Coleoptera & 31.57 & 1.62 \\
\hline & Chironomidae & 320.18 & 16.40 \\
\hline & other Diptera & 54.11 & 2.77 \\
\hline \multirow{8}{*}{ 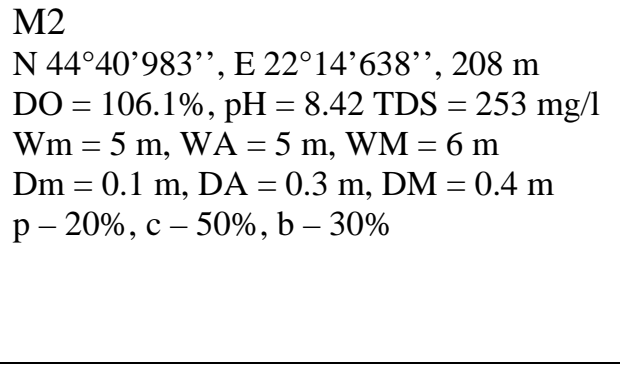 } & Oligochaeta & 121.76 & 16.88 \\
\hline & Amphypoda & 2.25 & 0.31 \\
\hline & Ephemeroptera & 306.65 & 42.50 \\
\hline & Plecoptera & 117.25 & 16.25 \\
\hline & Trichoptera & 63.13 & 8.75 \\
\hline & Coleoptera & 36.08 & 5.00 \\
\hline & Chironomidae & 51.86 & 7.19 \\
\hline & other Diptera & 22.55 & 3.13 \\
\hline \multirow{9}{*}{ 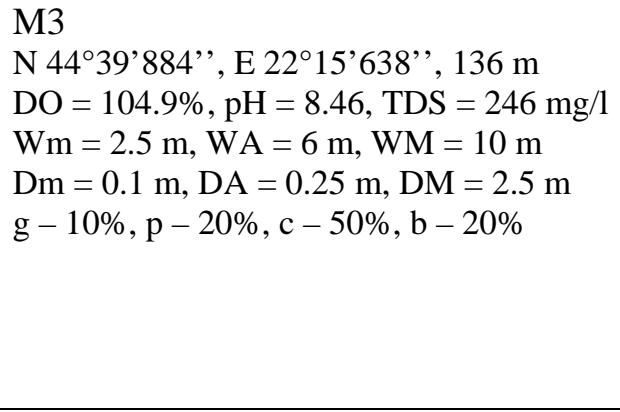 } & Oligochaeta & 218.71 & 10.59 \\
\hline & Hydracarina & 2.25 & 0.11 \\
\hline & Amphypoda & 27.06 & 1.31 \\
\hline & Ephemeroptera & 534.39 & 25.87 \\
\hline & Plecoptera & 182.64 & 8.84 \\
\hline & Trichoptera & 90.19 & 4.37 \\
\hline & Coleoptera & 15.78 & 0.76 \\
\hline & Chironomidae & 717.02 & 34.72 \\
\hline & other Diptera & 277.34 & 13.43 \\
\hline \multirow{8}{*}{ 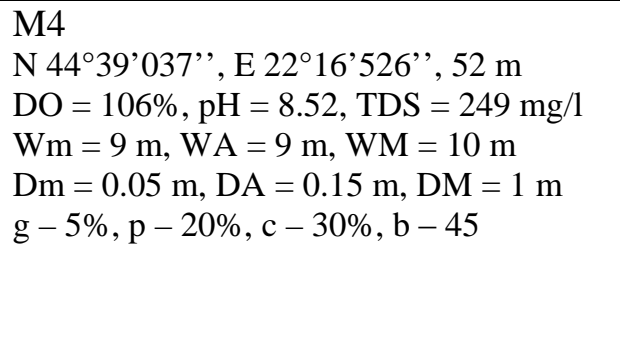 } & Oligochaeta & 124.01 & 10.93 \\
\hline & Amphypoda & 6.76 & 0.60 \\
\hline & Ephemeroptera & 426.16 & 37.57 \\
\hline & Plecoptera & 311.16 & 27.44 \\
\hline & Trichoptera & 103.72 & 9.15 \\
\hline & Coleoptera & 9.02 & 0.80 \\
\hline & Chironomidae & 112.74 & 9.94 \\
\hline & other Diptera & 40.59 & 3.58 \\
\hline
\end{tabular}




\section{CONCLUSIONS}

Longitudinally, benthic macroinvertebrate communities of the rivers Sirinia, Liubcova and Berzasca have a relatively high structural variability, and those of the Mraconia River have a lower structural variability.

In the case of the rivers Berzasca and Sirinia, a significant difference is clear between the structure of the communities of the river sector from $50 \mathrm{~m}$ upstream of the confluence with the Danube and the upstream communities. This difference is most likely due to the transition from the mountain lentic habitats upstream, and the habitats downstream, closer to the Danube confluence.

The structure of the benthic macroinvertebrate communities, in correlation with the biotope features, reveals that the studied rivers have a good ecological state, with the exception of the sector of the Berzasca River situated directly downstream from Berzasca Village and immediately upstream from the confluence with the Danube, which has a moderate condition, as a result of anthropic modification of the lotic biotope.

\section{ACKNOWLEDGEMENTS}

A part of this research was accomplished in the frame of the project "Southwestern Carpathian Wilderness and Sustainable Development Initiatives", co-financed by a Swiss grant through the contribution to the enlarged European Union. Special gratitude is addressed to the WWF Reşiţa members for all their friendly support in the field (in alphabetical order): Adăscăliței O., Berchi M., Crîsta R., Grancea A., Gavrilă C., and Sîrbu M. 


\section{REFERENCES}

1. Antonescu C. S., Udrescu M. and Oltean C., 1969 - Rezultate preliminare asupra cercetării râurilor Berzasca și Sirinea, Hidrobiologia, 10, 307-309. (in Romanian)

2. Badea L., (ed.), 1983 - Geografia României, I, Geografia Fizică, Edit. Academiei Române, 662. (in Romanian)

3. Botoşănenu L., 1959 - Cercetări asupra trichopterelor din Masivul Retezat și Munții Banatului, Edit. Academiei Române, 165. (in Romanian)

4. Buşniţă T., Brezeanu G., Oltean M., Popescu-Marinescu V. and Prunescu-Arion E., 1970 Monografia zonei Porţile de Fier. Studiu hidrobiologic al Dunării şi al afluenţilor săi, Edit. Academiei R. S. România, 266. (in Romanian)

5. Posea G., (ed.), 1982 - Enciclopedia Geografică a României, Edit. Ştiinţifică şi Enciclopedică, Bucureşti, 847. (in Romanian)

6. Prunescu-Arion E., 1968 - Contributions to the study of bentonic fauna of certain rivers of the zone of the future "Iron Gates" Dam lake, Travaux du Muséum National d'Histoire Naturelle “Grigore Antipa”, 8, 1, 143-161.

7. Roşu A., 1980 - Geografia Fizică a României, Edit. Didactică şi Pedagogică, Bucureşti, 484. (in Romanian)

8. Tetelea C., 2014 - Morphometric analysis to extrapolate geoecological potential of the rivers in the "Iron Gates" Natural park (Banat, Romania), Transylvanian Review of Systematical and Ecological Research, (in printing).

9. Ujvari I., 1972 - Hidrografia Republicii Populare Române, Edit. Ştiințifică, București, 577. (in Romanian) 